\title{
Oxygen-Isotope Ratios in the Blue Glacier, Olympic Mountains, Washington, U.S.A. ${ }^{1}$
}

\author{
Robert P. Sharp, Samueu Epstein, and Irene Vidziunas \\ California Institute of Technology \\ Pasadena, California
}

\begin{abstract}
The mean per mil deviation from a standard (average ocean water) in the $0^{10} / 0^{16}$ ratio of 291 specimens of ice, firn, snow, and rain from the Blue Glacier is -12.4 ; extremes are -8.6 and -19.2. This is consistent with the moist temperate climatological environment. The $0^{18} / 0^{16}$ ratio of snow decreases with declining temperature of precipitation, and it also decrease with increasing altitude at $0.5 / 100$ meters.

Analyses of the three principal types of ice, coarse-bubbly, coarse-clear, and fine, composing lower Blue Glacier, show that ratios for coarse-clear ice are generally lower and for fine ice they are mostly higher than the ratios for coarse-bubbly ice. This indicates that the fine ice represents masses of firn and snow recently incorporated into the glacier by filling of crevasses or by infolding in areas of severe deformation. Coarse-clear ice masses may represent fragments of coarse-bubbly ice within a breccia formed in the icefall. Because of unfavorable orientation, these fragments could have undergone exceptional recrystallization with reduction in air bubbles and, possibly, a relative decrease in $\mathrm{O}^{13}$.

A longitudinal septum in the lower Blue Glacier is characterized by higher than normal $\mathrm{O}^{10} / \mathrm{O}^{10}$ ratios. These values are consistent with an origin for this feature involving incorporation of much surficial snow and firn near the base of the icefall. Samples from longitudinal profiles on the ice tongue suggest that ice close to the snout comes from high parts of the accumulation area. Analyses from the light and dark bands of ogives are compatible with the concept that the dark bands represent greatly modified insets of firn-ice breccia filling icefall crevasses.

The range in ratios of materials is much greater in the accumulation area than in the ice tongue. This is attributed to homogenization, much of which takes place during the conversion of snow to glacier ice. This is supported by comparative analyses of snow layers when first deposited and months later. after alteration. Refreezing of rain and meltwater percolating into underlying cold snow is an important mechanism as shown by analyses of ice layers and lenses in the firn formed in this manner.
\end{abstract}

Introduction. Some potential uses of oxygenisotope data in glaciological research have been illustrated by analyses of samples from the Saskatchewan and Malaspina glaciers [Epstein and Sharp, 1959]. Other uses will be demonstrated by analyses of materials from Greenland [Benson, 1960; IGY Bull., 1959, pp. 82-83] and Antarctica, to be published shortly. The usefulness of the stable isotopes of oxygen and hydrogen in glaciological research rests on the fact that their range of abundance in snow is relatively large, far exceeding analytical errors of \pm 0.1 in the ratio values. The value and range of $0^{10} / 0^{10}$ ratios in glaciers depend principally upon meteorological conditions, especially upon the temperature at the time of snowfall. Thus the ratio varies with the storm, the season, the elevation, and other factors. The accumulation

1 Contribution No. 967, Division of Geological Sciences. area of a glacier acquires patterns in the distribution of $0^{19} / 0^{10}$ ratios which can be used as natural tracers. Although the ratios are modified during conversion of snow to ice and during subsequent flow within the glacier, this does not destroy their value as tracers. Among the modifying influences are freezing of meltwater and rain, capture of snow in crevasses, and homogenization by other unidentified processes. Thus the $0^{10} / 0^{16}$ ratios tell something about the original conditions of accumulation and reflect the influence of modifying processes during a subsequent history.

Oxygen-isotope studies of glaciers are still in a formative stage. The usefulness of this approach varies with the nature of a glacier, its environment, and the problems chosen for study. For example, the $0^{19} / 0^{18}$ ratios in snow on the Greenland ice sheet display simple relationships useful in stratigraphic correlation. In contrast, it 


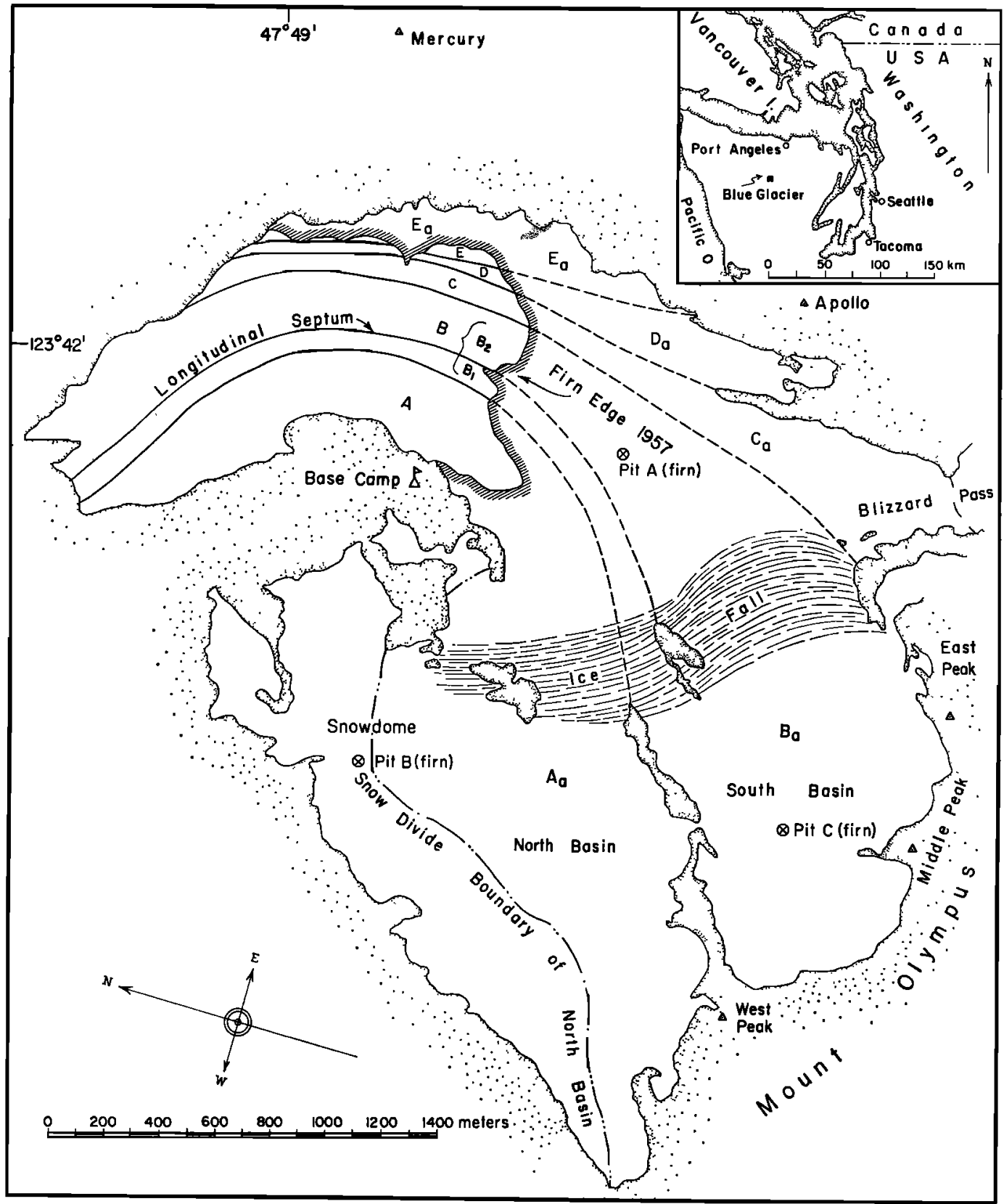

Fig. 1. Location, setting, shape and principal components of Blue Glacier.

appears that icefalls and temperate conditions with copious meltwater and rapid exchange of material lead to complications difficult to interpret. In investigations to date, the applicability of oxygen-isotope studies to all types of glaciers has not been satisfactorily defined. The present investigation was made in an attempt to determine the usefulness of the oxygen-isotope method on a small temperate glacier with a large material budget [LaChapelle, 1959, pp. 443-446].

The Blue Glacier was selected because it is relatively small, geometrically simple, and easily accessible; its constitution and structure are 
known [Allen, Kamb, Meier, and Sharp, 1960], and associated glaciological and meteorological studies contribute to an understanding of oxygen-isotope relationships. The principal items investigated are (1) the range and mean value of $0^{18} / 0^{18}$ ratios as related to general environmental conditions and to the theory of oxygenisotope fractionation; (2) the influence of altitude and temperature on $0^{18} / 0^{18}$ ratios; (3) changes in isotope ratios within firn layers during alteration; (4) differences in isotope ratios of the three principal types of ice, coarse-bubbly, coarse-clear, and fine, composing this glacier and their bearing on the origin and history of these types of ice; (5) differences in isotope ratios of ice coming from various accumulation areas; (6) variations in isotope ratios along longitudinal profiles on the surface of the ice tongue below the firn edge and their relation to flow lines within the glacier; (7) differences in isotope ratios of the materials composing ogive bands as an aid in understanding the origin of this structure; and (8) changes in oxygen-isotope ratios, if any, produced by recrystallization, changes of state, and other processes related to solid flow.

A general program of glaciological research was begun on Blue Glacier in the summer of 1957; it has extended through 1960 and will be continued, with the permission of the National Park Service. It was preceded by Park Service observations in the 1940's and early $1950^{\prime} \mathrm{s}$ and glaciological and glacio-meteorological work during 1955 and 1956 [Hubley, 1957], and it has been accompanied by glacio-meteorological research on upper Blue Glacier from 1957 to 1959 [LaChapelle, 1958, 1959]. Samples for oxygenisotope analyses were collected during the winter of 1957-1958 and in the summers of 1958 and 1959.

Physical setting and constitution of the Blue Glacier. The Blue Glacier is a small ice stream that rises high on the northeastern slope of Mount Olympus $(2413 \mathrm{~m})$ in the heart of the Olympic Mountains of northwestern Washington (Fig. 1). This glacier is $4.3 \mathrm{~km}$ long and $1 \mathrm{~km}$ wide at the firn edge; it covers $4.3 \mathrm{~km}^{2}$ and descends from a maximum elevation of $2375 \mathrm{~m}$ to a terminus at $1265 \mathrm{~m}$. The firn edge has an approximate elevation of $1600 \mathrm{~m}$, and the bare ice tongue extends $2 \mathrm{~km}$ farther down the valley. A major icefall, $300 \mathrm{~m}$ high, $0.8 \mathrm{~km}$ upglacier from the edge of the firn, separates lower Blue Glacier from its principal accumulation basins, termed 'upper Blue Glacier.' The Blue Glacier, supposedly temperate, has a high rate of mass exchange owing to heavy accumulation and strong ablation [LaChapelle, 1959, p. 445].

The climatological environment is strongly maritime, that is, relatively warm and moist. Records from the Snowdome station at $2070 \mathrm{~m}$ on upper Blue Glacier [LaChapelle, 1958, p. 12] for the period August 1, 1957, to July 31, 1958, show a mean annual temperature of $1.6^{\circ} \mathrm{C}$ $\left(34.9^{\circ} \mathrm{F}\right)$, a mean for the coldest month (March) of $-6.1^{\circ} \mathrm{C}\left(+21.1^{\circ} \mathrm{F}\right)$, and a mean minimum for March of $-8.9^{\circ} \mathrm{C}\left(16.1^{\circ} \mathrm{F}\right)$. The lowest temperature recorded was $-15^{\circ} \mathrm{C}\left(5^{\circ} \mathrm{F}\right)$ and the highest $21.7^{\circ} \mathrm{C}\left(71^{\circ} \mathrm{F}\right)$. Total precipitation was $378 \mathrm{~cm}$ (148.9 inches) of water, of which $305 \mathrm{~cm}$ (119.7 inches), or 80 per cent, fell as snow, This period of observation was unusually warm and dry, judging from records at other meteorological stations in northwestern Washington, and the above figures are not representative of longrange means. In an average year the mean annual precipitation on Snowdome may exceed $500 \mathrm{~cm}$ (200 inches) of water.

Lower Blue Glacier consists of two major and three minor ice streams, each originating in separate accumulation areas (Fig. 1). Only major streams $A$ and $B$ extend to the snout; minor streams $\mathrm{C}, \mathrm{D}$, and $\mathrm{E}$ terminate along the east margin. Ice stream B consists of two currents below the icefall separated by an intensely foliated, structurally complex zone, the longitudinal septum, which is unusually rich in fine ice and coarse-clear ice. This septum separates two arc-shaped foliation patterns displayed by composite ice streams $\mathrm{A}+\mathrm{B}_{1}$ and $\mathrm{B}_{2}+\mathrm{C}$ (Fig. 1). Ice stream $A$ also displays a series of weak ogives of the internal variety. Details of these and other structures are given elsewhere [Allen, Kamb, Meier, and Sharp, 1960].

Sampling and analysis. The method of analysis has been described elsewhere [Epstein and Mayeda, 1953, p. 214] and will not be reviewed here. In this paper, the result of an analysis is expressed as a relative, per mil deviation of the $0^{10} / 0^{10}$ ratio of the sample from the ratio of a standard-in this instance, mean ocean water. This value, termed 8 , is calculated in the following manner. 
TABLE 1. Oxygen-Isotope Ratios in Ice of a Core Taken 150 Meters below the Firn Edge in Ice Stream B, August 22, 1958

\begin{tabular}{|c|c|}
\hline $\begin{array}{l}\text { Depth, } \\
\text { cm }\end{array}$ & $\begin{array}{c}\delta \text { Value of } \\
0^{18} / O^{18} \text { Ratio }\end{array}$ \\
\hline $\begin{array}{r}30.5 \\
61.0 \\
91.5 \\
122.0 \\
152.5 \\
183.0 \\
213.5 \\
244.0 \\
274.5 \\
305.0\end{array}$ & $\begin{array}{l}-12.5 \\
-12.5 \\
-12.3 \\
-12.8 \\
-12.8 \\
-12.8 \\
-12.9 \\
-12.5 \\
-12.4 \\
-12.5\end{array}$ \\
\hline & -12.6 \\
\hline
\end{tabular}

$\delta=\left[\frac{\mathrm{H}_{2} \mathrm{O}^{18} / \mathrm{H}_{2} \mathrm{O}^{18} \text { (sample) }}{\mathrm{H}_{2} \mathrm{O}^{18} / \mathrm{H}_{2} \mathrm{O}^{16}(\text { mean ocean water })}-1\right]$ $\times 1000$

In such an arrangement the $\delta$ for mean ocean water is zero. Since the $0^{18} / O^{10}$ ratio of all natural precipitation is lower than that of mean ocean water, the $\delta$ of such precipitation is always negative in this arbitrary system.

Accurate analyses of the materials composing a glacier are of limited value unless the signifcance of the specimen is fully understood in terms of the field relations. A clear understanding of structural relations and a recognition of the different types of ice on the Blue Glacier proved necessary for intelligent sampling, and specimens had to be collected with specific objectives in view.

The practice has been to dig to fresh-looking ice 10 to $20 \mathrm{~cm}$ beneath the surface before taking a sample, in order to eliminate possible surface effects. The data of Table 1 suggest that the near surface samples are reasonably representative of ice to a depth of at least $3 \mathrm{~m}$. Data from core samples to that depth display a relatively high degree of homogeneity, the range in 8 values being only $0.6(-12.3$ to -12.9$)$. This compares nicely with a detailed surface traverse of similar dimensions on the Saskatchewan Glacier [Epstein and Sharp, 1959, p. 100], where the difference was $0.5(-20.1$ to -20.6$)$.

Proper care of samples is necessary. It is particularly important that evaporation subsequent to collection be prevented. Our practice has been to place enough material in small-mouthed plastic bottles to make 25 to 50 cc of water when melted. The bakelite caps should be tested for tightness several times after collection. Possible evaporation can be observed by reference to lines drawn at water level on the outside of the bottles or by indenting the bottles slightly with the fingers before capping. If the indentation remains, the cap is obviously tight. Samples should be transferred to glass bottles in the laboratory if they are to be stored for a considerable length of time.

Oxygen-isotope ratios in relation to the climatological environment. The mean $\delta$ of 291 specimens from all parts of the Blue Glacier, representing glacier ice, firn, snow, and rain, is -12.4 . This is not a truly representative figure, as it does not give weight in proper proportions to the different materials; nonetheless it is a reasonable figure. The extremes recorded are -8.6 and -19.2 . These values confirm the basic hypothesis concerning fractionation of oxygen isotopes in natural precipitation [Epstein and Mayeda, 1953, p. 220]. The Olympic Mountains lie in a moist, temperate environment that is not exceptionally cold even in winter. As theory predicts, these conditions yield only moderately low $\delta$ values as compared with much lower values from glaciers in truly cold environments.

Until 1957-1958 essentially nothing was known from direct measurement of the meteorological conditions prevailing on Mount Olympus in win-

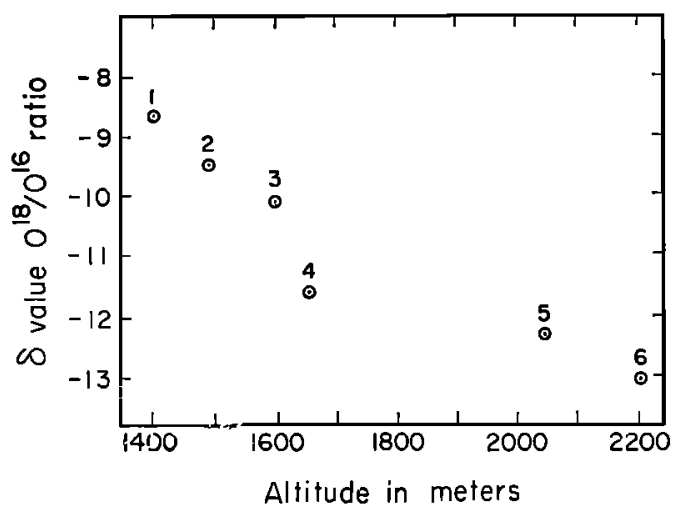

Fig. 2. Relationship between altitude and $\delta$ values of $0^{18} / 0^{10}$ ratio in mow and firn on Blue Glacier. 1, snow in crevasse; 2, anow on glacier; 3, snow bank; 4, average of 13 samples of 1957-1958 snow, pit $A$; 5 , average of 18 samples of 1958-1959 anow, pit $B$; 6 , average of 45 samples of 1958-1959 mow, pit $C$. 
TABLE 2. Changes in $\mathrm{O}^{18} / \mathrm{O}^{18}$ Ratio with Altitude at Various Localities

\begin{tabular}{|c|c|c|}
\hline Locality & $\begin{array}{l}\text { Latitude and } \\
\text { Longitude }\end{array}$ & $\begin{array}{c}\text { Change in } \\
\delta \text { Value of } \\
0^{18} / 0^{16} \\
\text { Ratio per } \\
100-m \\
\text { Altitude }\end{array}$ \\
\hline $\begin{array}{l}\text { Northwestern } \\
\text { Greenland } \\
\text { Saskatchewan } \\
\text { Glacier, Alberta, } \\
\text { Canada } \\
\text { Sierra Nevada, } \\
\text { Calif. } \\
\text { Sierra Madre } \\
\text { (Mountains), } \\
\text { Calif. } \\
\text { Blue Glacier, Wash. }\end{array}$ & $\begin{array}{l}70-78^{\circ} \mathrm{N} ; 40-65^{\circ} \mathrm{W} \\
52^{\circ} 08^{\prime} \mathrm{N} ; 117^{\circ} 12^{\prime} \mathrm{W} \\
39^{\circ} \mathrm{N} ; 120^{\circ} \mathrm{W}\end{array}$ & $\begin{array}{l}0.2 \\
0.3\end{array}$ \\
\hline
\end{tabular}

ter. The upper Blue Glacier study [LaChapelle, 1958, p. 12] now provides such information, and the oxygen-isotope ratios are compatible with these meteorological data.
Effects of altitude. The altitude at which condensation occurs in clouds affects the $0^{10} / 0^{10}$ ratio of the precipitate [Epstein, 1959, pp. 224 228 ], the $\delta$ becoming lower with increasing altitude. Measurements would best be made on samples collected at various elevations during corresponding stages of a single storm. On Blue Glacier this was not possible, and samples were taken from remnants of snow found at various elevations. This procedure is open to criticism, as it does not eliminate seasonal variations. Nonetheless, the data (Fig. 2) show a reasonably consistent relation between $\delta$ and altitude. The value becomes lower with increasing altitude at a rate of 0.5 per 100 meters. As is shown in Table 2, this is a steeper gradient than that recorded in some areas, but it is not as steep as the one in Greenland. Since the magnitude of the altitudinal effect must also be influenced by temperature gradient, altitude gradient, and the nature of individual storms, it is hardly likely to be the same in different places.

Current precipitation. Glacier ice is old in the sense that it consists largely of material ac-

TABLE 3. Samples of Current Precipitation

\begin{tabular}{|c|c|c|c|c|c|}
\hline $\begin{array}{l}\text { Nature } \\
\text { of } \\
\text { Material }\end{array}$ & $\begin{array}{l}\text { Date and Hour } \\
\text { Collected }\end{array}$ & Location & $\begin{array}{l}\text { Temperature } \\
\text { at Time of } \\
\text { Collection, }{ }^{\circ} \mathrm{C}\end{array}$ & Comments & $\begin{array}{c}8 \text { Value of } \\
\text { O'18/010 }^{10} \\
\text { Ratio }\end{array}$ \\
\hline $\begin{array}{l}\text { Snow } \\
\text { Snow } \\
\text { Snow }\end{array}$ & $\begin{array}{l}1 / 7 / 58,1400 \\
1 / 8 / 58,1000 \\
1 / 8 / 58,1600\end{array}$ & $\begin{array}{l}\text { Snowdome } \\
\text { Snowdome } \\
\text { Snowdome }\end{array}$ & $\begin{array}{l}-2 \\
-5 \\
-8\end{array}$ & $\begin{array}{l}\text { Fresh, wind-blown } \\
\text { Fresh, wind-blown } \\
\text { Probably fresh, wind- } \\
\text { blown }\end{array}$ & $\begin{array}{l}-10.2 \\
-11.5 \\
-13.5\end{array}$ \\
\hline $\begin{array}{l}\text { Snow } \\
\text { Snow } \\
\text { Snow }\end{array}$ & $\begin{array}{l}1 / 9 / 58,0930 \\
1 / 10 / 58,1000 \\
1 / 11 / 58,1000\end{array}$ & $\begin{array}{l}\text { Snowdome } \\
\text { Snowdome } \\
\text { Snowdome }\end{array}$ & $\begin{array}{l}-4 \\
-3 \\
-6\end{array}$ & $\begin{array}{l}\text { Fresh, wind-blown } \\
\text { Fresh, wind-blown } \\
\text { Wind-blown, probably } \\
\text { reworked }\end{array}$ & $\begin{array}{l}-13.9 \\
-13.1 \\
-17.4\end{array}$ \\
\hline $\begin{array}{l}\text { Snow } \\
\text { Snow } \\
\text { Snow } \\
\text { Snow } \\
\text { Snow } \\
\text { Snow } \\
\text { Snow }\end{array}$ & $\begin{array}{l}1 / 12 / 58,0930 \\
1 / 13 / 58,0930 \\
1 / 15 / 58,1000 \\
1 / 16 / 58,0900 \\
2 / 9 / 58,1130 \\
2 / 17 / 58,1430 \\
3 / 6 / 58,1004\end{array}$ & $\begin{array}{l}\text { Snowdome } \\
\text { Snowdome } \\
\text { Snowdome } \\
\text { Snowdome } \\
\text { Snowdome } \\
\text { Snowdome } \\
\text { Snowdome, east } \\
\text { slope }\end{array}$ & $\begin{array}{c}-4.5 \\
-7 \\
-2 \\
0 \\
-4.4 \\
0 \\
-11.1\end{array}$ & $\begin{array}{l}\text { Fresh, wind-blown } \\
\text { Wind-blown, reworked } \\
\text { Fresh, from surface } \\
\text { Fresh, from surface } \\
\text { Fresh, from surface } \\
\text { Fresh, from surface } \\
\text { Fresh powder snow }\end{array}$ & $\begin{array}{r}-15.7 \\
-15.3 \\
-9.1 \\
-14.3 \\
-16.7 \\
-13.9 \\
-13.4\end{array}$ \\
\hline Snow & $3 / 6 / 58,1127$ & $\begin{array}{l}\text { Snowdome, SW of } \\
\text { center }\end{array}$ & -1.1 & Fresh powder enow & -11.0 \\
\hline $\begin{array}{l}\text { Snow } \\
\text { Snow } \\
\text { Snow }\end{array}$ & $\begin{array}{l}3 / 8 / 58,0900 \\
3 / 28 / 58,1330 \\
3 / 30 / 58,0830\end{array}$ & $\begin{array}{l}\text { Snowdome } \\
\text { Snowdome } \\
\text { Snowdome }\end{array}$ & $\begin{array}{r}-10.0 \\
-1.0 \\
-7.0\end{array}$ & $\begin{array}{l}\text { Fresh from surface } \\
\text { Wind-blown } \\
\text { From surface, worked } \\
\text { by wind }\end{array}$ & $\begin{array}{l}-14.1 \\
-11.9 \\
-19.2\end{array}$ \\
\hline $\begin{array}{l}\text { Snow } \\
\text { Snow } \\
\text { Rain } \\
\text { Rain }\end{array}$ & $\begin{array}{l}4 / 21 / 58,1300 \\
4 / 24 / 58,1330 \\
8 / 18 / 59,1600 \\
8 / 22 / 59,0600\end{array}$ & $\begin{array}{l}\text { Snowdome } \\
\text { Snowdome } \\
\text { Caltech base camp } \\
\text { Caltech base camp }\end{array}$ & $\begin{array}{l}-5.5 \\
-3.3 \\
+7 \text { (est.) } \\
+3 \text { (est.) }\end{array}$ & $\begin{array}{l}\text { Fresh, from surface } \\
\text { Fresh, from surface }\end{array}$ & $\begin{array}{r}-12.5 \\
-17.2 \\
-9.1 \\
-10.6\end{array}$ \\
\hline
\end{tabular}


cumulated tens, hundreds, or even thousands of years ago. By way of comparison it is worth looking at oxygen-isotope ratios in current precipitation on the Blue Glacier, chiefly in the form of new-fallen snow, collected during the winter of 1957-1958 by the group on Snowdome.

The $\delta$ for rain samples from the Caltech base camp are higher (Table 3) than those for snow on Snowdome. This is to be expected because the elevation of the Caltech camp is $445 \mathrm{~m}$ lower and because the samples from the camp were collected in the summer and those from Snowdome were collected in the winter. Values for the snow samples decrease with declining temperature of precipitation. It is also apparent (Table 3) that a number of the snow layers deposited during windy periods have lower values than snow not blown by wind. The mean $\delta$ of ten wind-blown samples is -14.2 , compared with -13.5 for eight noneolian specimens. Even though this difference is small, it may be significant. Temperature does not seem to be the controlling influence, as it was slightly higher during accumulation of the wind-blown material $\left(4.8^{\circ} \mathrm{C}\right.$ as compared with $4.6^{\circ} \mathrm{C}$ ). There is no basis in theory for thinking that evaporation associated with wind action would reduce the relative amount of $\mathrm{O}^{18}$, and condensation could either raise or lower the value depending upon the nature of the condensing moisture. The true explanation may lie in basic differences in windy storms and in their histories of precipitation prior to their arrival on Mount Olympus.

The average $\delta$ for snow from Snowdome is somewhat lower $(-13.9)$ than the average for all samples from the ice tongue $(-12.1)$. Furthermore, the range of values for the snow $(-9.1$ to -19.2$)$ is much greater than for the materials of the ice tongue $(-10.3$ to -14.1$)$, as is shown by bars $S$ and $E$ in Figure 3. These data suggest a considerable homogenization, much of which occurs during conversion of snow to glacier ice and which probably continues at a reduced rate during the subsequent history of ice in the glacier (compare $D$ of Fig. 3 with $A$, $B$, and $C$ ). A moderate relative enrichment in $\mathrm{O}^{18}$ also takes place. This could be brought about either by adding $O^{18}$ or by removing $O^{16}$. The analyses do not indicate that old, far-traveled ice has been enriched in $\mathrm{O}^{18}$, as compared with young, less-traveled ice (Fig. 5). Actually, they suggest the reverse, although the interpretation

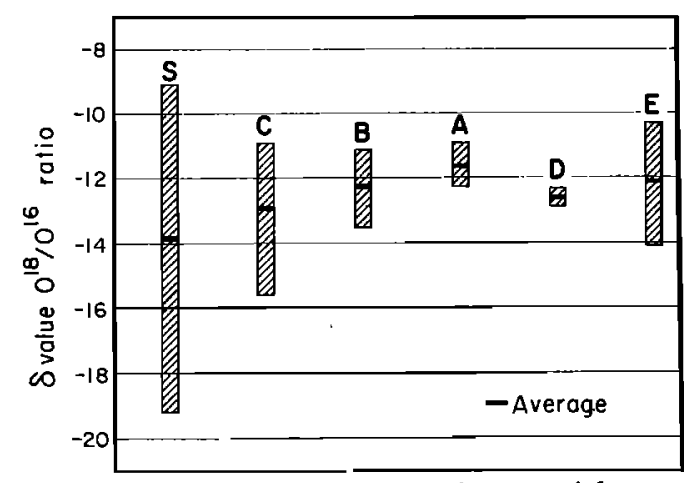

Fig. 3. Range of $\delta$ values in materials at following sites: $\mathbf{S}$, specimens of fresh onow collected on Snowdome, winter of 19571958. $A$, pit in firn on lower Blue Glacier at elevation $1654 \mathrm{~m}$ as sampled August 7, 1958. $B$, pit in firn on Snowdome at elevation 2045 $\mathrm{m}$ as sampled August, 18, 1958. C, pit in South Basin (Fig. 1) at elevation $2205 \mathrm{~m}$ as sampled on August 9 and 18, 1958. $D, 3$-meter core hole in ice $150 \mathrm{~m}$ below firn edge as collected August 22, 1958. $E$, all samples from ice tongue below edge of the firn. Black bar indicates average $\delta$ value.

is complicated by the fact that the older ice probably originated at a higher altitude and its $\delta$ values should be somewhat lower for that reason. Changes occurring within the firn are probably a more likely cause of relative enrichment in $\mathrm{O}^{\text {ts }}$ and also of much of the homogenization. It seems unlikely that the differences in average $\delta$ values of samples from Snowdome and from the ice tongue reflect a secular climatic change, in view of the relatively small secular change in temperature in this region over past decades [Hubley, 1956, p. 673; Landsberg, 1960, p. 1520].

One possible mechanism of homogenization and $\mathrm{O}^{18}$ enrichment is the refreezing of the meltwater and rain water that percolate into cold, underlying snow or firn. In an annual layer of snow, before the melting season, the part that accumulates in winter has the greatest reservoir of cold and, on the average, the lower $\delta$ values. This winter snow is initially overlain by spring and possibly early-summer snows which precipitated under warmer conditions and consequently have high $\delta$ values. Meltwater that percolates into the cold winter layers comes from these surface snows of high $\delta$ values. The difference in $\delta$ is probably even more marked in the instance of rain water, although much of 
TABLE 4. Changes in $0^{18} / \mathrm{O}^{10}$ Ratio of Specific Snow Layers with Time for Samples from Snowdome

\begin{tabular}{|c|c|c|c|}
\hline $\begin{array}{l}\text { Sample } \\
\text { Number }\end{array}$ & $\begin{array}{c}\text { Date } \\
\text { Collected }\end{array}$ & Description & $\begin{array}{c}8 \text { Value of } \\
\text { O18/O' }^{16} \\
\text { Ratio }\end{array}$ \\
\hline \multicolumn{4}{|l|}{ Series I } \\
\hline 1 & $2 / 9 / 58$ & $\begin{array}{l}\text { Surface of a deep layer } \\
\text { of new snow, } \\
\text { marked for recovery }\end{array}$ & -16.4 \\
\hline 2 & $6 / 22 / 58$ & $\begin{array}{l}\text { Collected from the } \\
\text { same layer as } \\
\text { aample } 1 \text { now re- } \\
\text { exposed at surface } \\
\text { (from open snow } \\
\text { eurface) }\end{array}$ & -12.8 \\
\hline 3 & $6 / 22 / 58$ & $\begin{array}{l}\text { Same layer as sample } \\
1 \text {, protected by a } \\
\text { tin can }\end{array}$ & -12.9 \\
\hline 4 & $6 / 22 / 58$ & $\begin{array}{r}\text { Same layer as sample } \\
1 \text {, protected by } 1 \mathrm{sq} \\
\text { ft of aluminum foil }\end{array}$ & -13.1 \\
\hline \multicolumn{4}{|l|}{ Series II } \\
\hline 5 & $2 / 17 / 58$ & $\begin{array}{l}\text { Surface of now snow } \\
\text { layer }\end{array}$ & -13.9 \\
\hline 6 & $6 / 16 / 58$ & $\begin{array}{l}\text { Same layer as sample } \\
5 \text {, from open ex- } \\
\text { posed surface }\end{array}$ & -13.2 \\
\hline 7 & $6 / 16 / 58$ & $\begin{array}{l}\text { Same layer as sample } \\
5 \text {, protected by tin } \\
\text { can }\end{array}$ & -14.6 \\
\hline 8 & $6 / 16 / 58$ & $\begin{array}{l}\text { Same layer as sample } \\
\text { 5, protected by } \\
\text { aluminum foil }\end{array}$ & -14.3 \\
\hline \multicolumn{4}{|c|}{ Series III } \\
\hline 9 & $3 / 8 / 58$ & $\begin{array}{l}\text { Surface of new snow } \\
\text { layer }\end{array}$ & -14.1 \\
\hline 10 & $6 / 5 / 58$ & $\begin{array}{l}\text { Same layer as sample } \\
9, \text { not protected }\end{array}$ & -13.6 \\
\hline 11 & $6 / 5 / 58$ & $\begin{array}{l}\text { Same layer as sample } \\
9 \text {, protected by tin } \\
\text { can }\end{array}$ & -13.9 \\
\hline
\end{tabular}

the cold reserve in the snow has probably been eliminated before much rain falls. Refreezing of percolating meltwater, and to a limited degree of rain, in the cold winter snows is believed to be an important factor in the homogenization and relative enrichment in $\mathrm{O}^{18}$ within the snow that survives the ablation season. This is the material, of course, that ultimately makes up the ice tongue. Homogenization may continue after the firn is raised to the freezing temperature through exchange of oxygen between the firn and percolating water. This should be a slow process, and it has not been evaluated by actual measurements.

An attempt to measure the rate of homogenization was made through cooperation of the Snowdome group by sampling layers of snow when they first accumulated and resampling them months later after they had undergone considerable alteration. The results (Table 4), though interesting, are not entirely consistent or compelling. For example, the snow layer that accumulated on February 9, 1958, had a decidedly higher $\delta$ when resampled on June 22, 1958. Part of this may have been due to its freewater content in June, which could have been in the neighborhood of 10 per cent by weight (LaChapelle, personal communication), but most of the difference was presumably due to the refreezing of water percolating down from the surface in late spring. An attempt to evaluate the effects of percolation was made by protecting part of the same snow layer by means of impermeable coverings. The difference in the samples so protected is consistent with a reduced percolation, but it is not of great magnitude. It may be that the percolating waters gained considerable access to the covered snow through lateral capillary channels and that the protection was only partly effective.

The $\delta$ values for the snow layers of February 17 and March 8 (Table 4) had also become higher when resampled on June 16 and June 5, respectively, but the change was much less than that in the snow layer of February 9 . The shielded part of the March 8 layer showed a smaller change than the unshielded material, which would be expected if it had received less meltwater. However, the shielded samples of the February 17 layer had lower $\delta$ values than the original snow. This is an unexpected result for which no satisfactory explanation has yet been found. The sampling procedure may be at fault. It is known that the $\delta$ for ice layers and lenses in firn sections (Table 5) is generally higher than that in the adjacent firn layers. Since the ice bodies are formed by refreezing of percolated meltwater, they indicate that relative enrichment of $\mathrm{O}^{18}$ by this mechanism does occur.

Oxygen-isotope ratios in firn. Knowledge of oxygen-isotope ratios within the firn of the accumulation area is valuable, as this is the source of the material composing the ice tongue of the glacier. In August 1958, samples were taken 
TABLE 5. Oxygen-Isotope Ratios in 1957-1958 Firn from Pits on Blue Glacier

\begin{tabular}{cc}
$\begin{array}{c}\text { Depth, } \\
\text { cm }\end{array}$ & $\begin{array}{c}\delta \text { Value of } \\
0^{18} / 0^{10} \text { Ratio }\end{array}$ \\
\hline
\end{tabular}

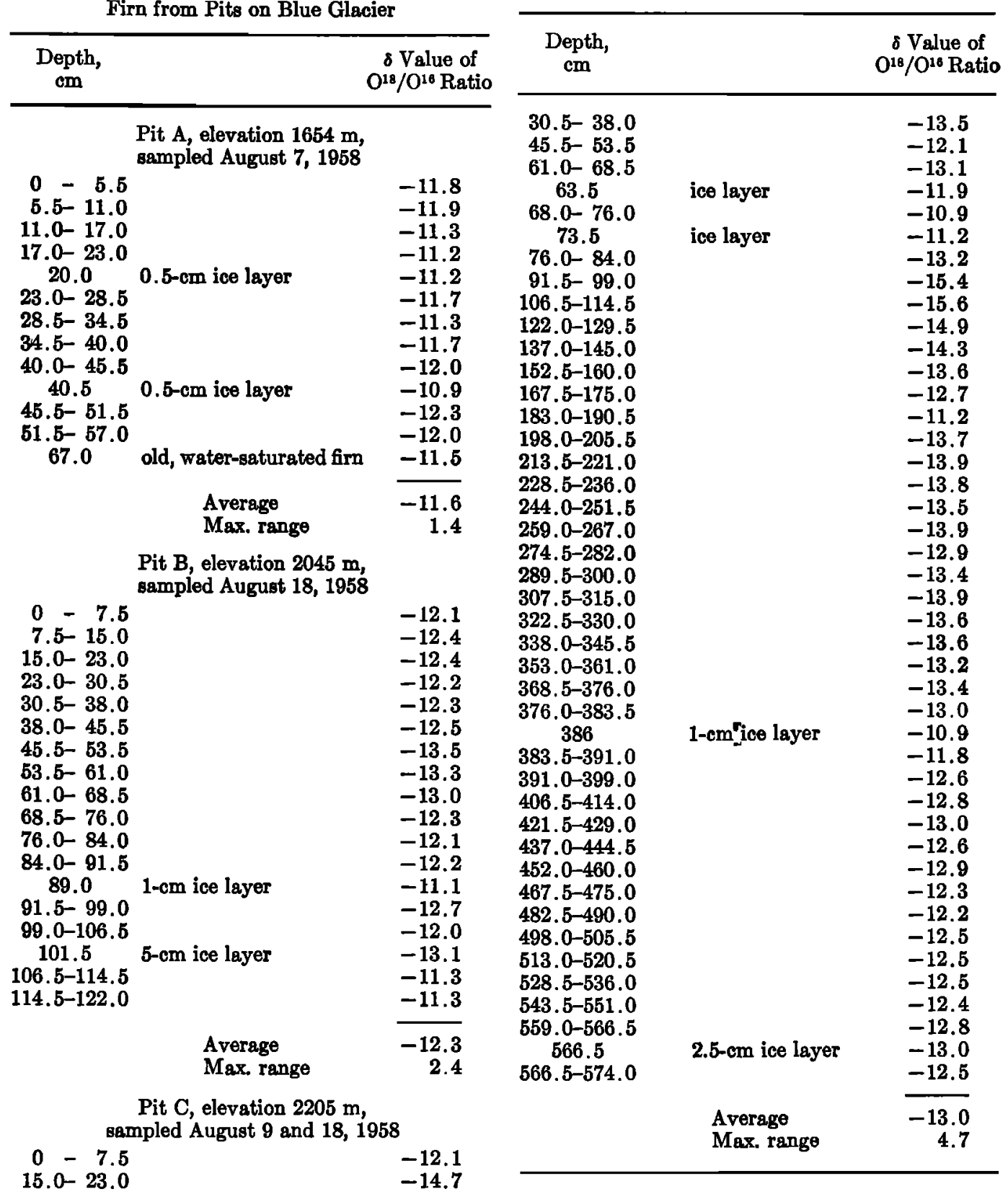

from pits in the 1957-1958 annual firn layer at three sites spanning the maximum possible vertical $(550 \mathrm{~m})$ and horizontal $(1.4 \mathrm{~km})$ range. Continuous channel sampling was used, each specimen representing a thickness between 5.5 and $7.5 \mathrm{~cm}$. Ice layers and lenses within the firn were separately sampled. The sections sampled
TABLE 5. Continued

do not represent a complete annual layer, as much material had been lost at the top through ablation. The section at pit $\mathrm{C}$ (altitude $2205 \mathrm{~m}$ ) was by far the thickest and most complete (Fig. 4) and had unquestionably undergone the least alteration.

The data (Table 5) confirm the trend and 


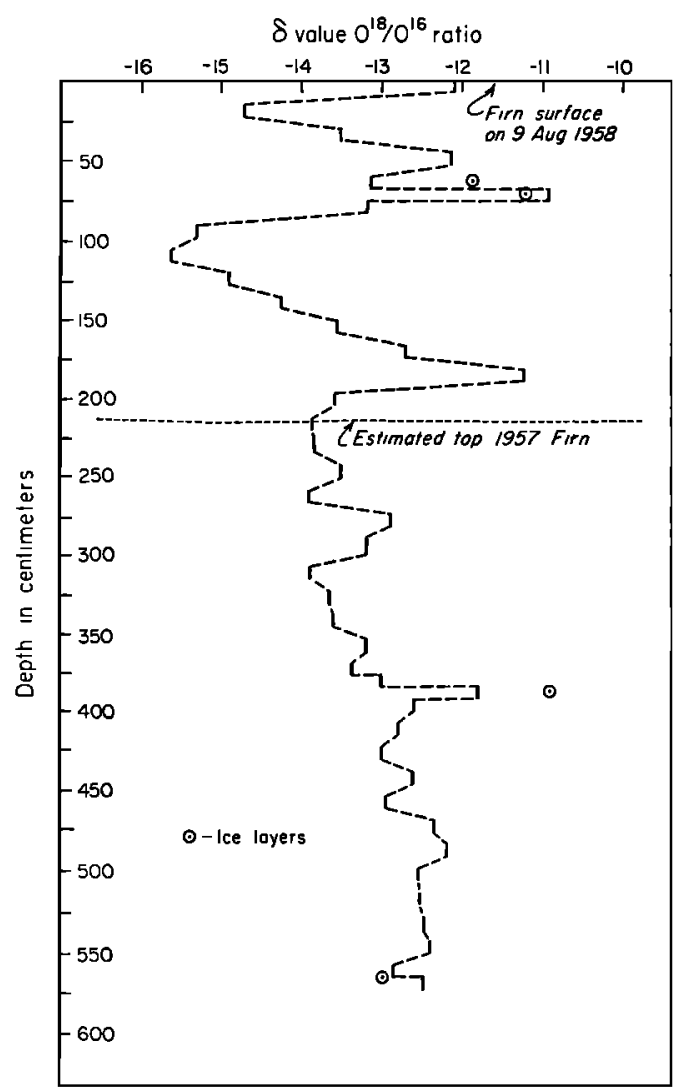

Fig. 4. $0^{19} / 0^{10}$ ratios in firn and ice layers of pit $C$, elevation $2205 \mathrm{~m}$.

general magnitude of the altitudinal influence on $0^{10} / 0^{10}$ ratios (Fig. 3 ). The range in $\delta$ values also increases with altitude, being 1.4 at pit $\mathrm{A}$ $(1654 \mathrm{~m}) ; 2.4$ at pit $B(2045 \mathrm{~m})$, and 4.8 at pit $C(2205 \mathrm{~m})$. Since the range of values in new-fallen snow collected near the site of pit B is still greater, 10.1 (Table 5), the conclusion is permissible that the decrease in range at lower altitudes is at least in part a matter of increasing homogenization. The firn at lower elevations has simply been permeated by greater amounts of meltwater over a longer interval of time. Five of the specimens from pit $C$ have a lower $\delta$ than any sample from the ice tongue, and it seems that during the process of homogenization a relative increase of $\mathrm{O}^{18}$ in the materials of the tongue has occurred. These relationships are borne out graphically in Figure 4, which shows that the frequency and range of variations within the 1958 layer clearly exceed those in the underlying firn. Furthermore, a small but steady en- richment in $\mathrm{O}^{\text {1s }}$ with depth is indicated. A comparison of 'new' firn (-11.2) and 'old' firn $(-10.6)$ at the firn edge shows the same trend.

Ice layers and lenses in firn are formed by the refreezing of water that percolates down from the surface and spreads out along a particularly stratigraphic layer [Sharp, 1951, p. 613; Benson, 1960, pp. 38-40]. For reasons already discussed, these ice bodies should have $\delta$ values higher than those in the adjacent firn. This proved to be the case for six out of eight ice layers and lenses in the firn pits of the Blue Glacier. The exceptions constitute an unsolved problem similar to that encountered in pits on Saskatchewan Glacier [Epstein and Sharp, 1959, p. 94]. It may be that the original snow layers had such low $\delta$ values that permeation with meltwater did not bring the value up to that of the adjacent layers.

Types of ice. The tongue of lower Blue Glacier consists principally of three types of ice, arbitrarily identified as coarse bubbly, coarse clear, and fine. ${ }^{2}$ The fine ice is also bubbly, and all three types are described in more detail elsewhere $[K a m b, 1959$, p. 1893 ; Allen, Kamb, Meier, and Sharp, 1960]. In many instances, closely associated specimens of these types of ice display significant differences in $\delta$ values (Fig. 6, Table 6) which may reflect differences in genesis and history. In most places coarsebubbly ice constitutes at least 90 per cent of the exposed material. It is considered to be the 'normal' or 'average' ice, and its $\delta$ provides a datum for comparison with other types of ice.

Coarse-clear ice occurs in close association with both coarse-bubbly and fine ice. In some places it is in sharply defined masses, and in others the transition into coarse-bubbly ice is gradual. At most localities the $\delta$ values for coarse-clear ice are distinctly lower than the values obtained for adjacent coarse-bubbly ice. The mean difference in the values for 30 closely associated coarse-bubbly and coarse-clear ice pairs is -0.4 , and the maximum is -2.0 . In 6 out of the 30 pairs the $\delta$ of coarse-clear ice was higher, but in 3 of these the difference was only +0.1. The $\delta$ of coarse-clear ice is also lower than that of associated fine ice in nearly all instances, although one striking exception was

2 This or similar material has been called granulated ice [Epstein and Sharp, 1959, p. 99] or firn ice (Firneis) [Klebelsberg, 1948, p. 39-40]. 


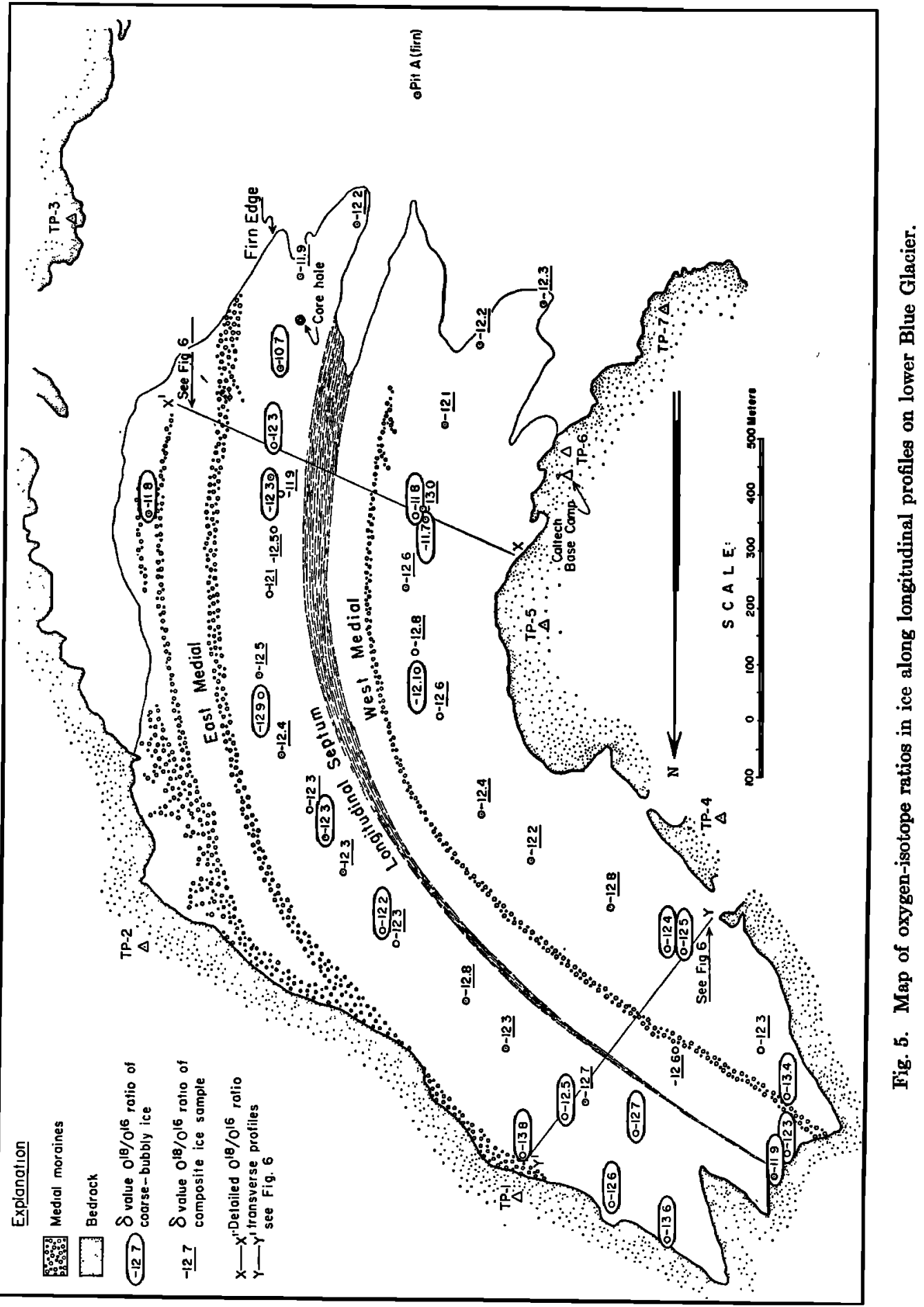



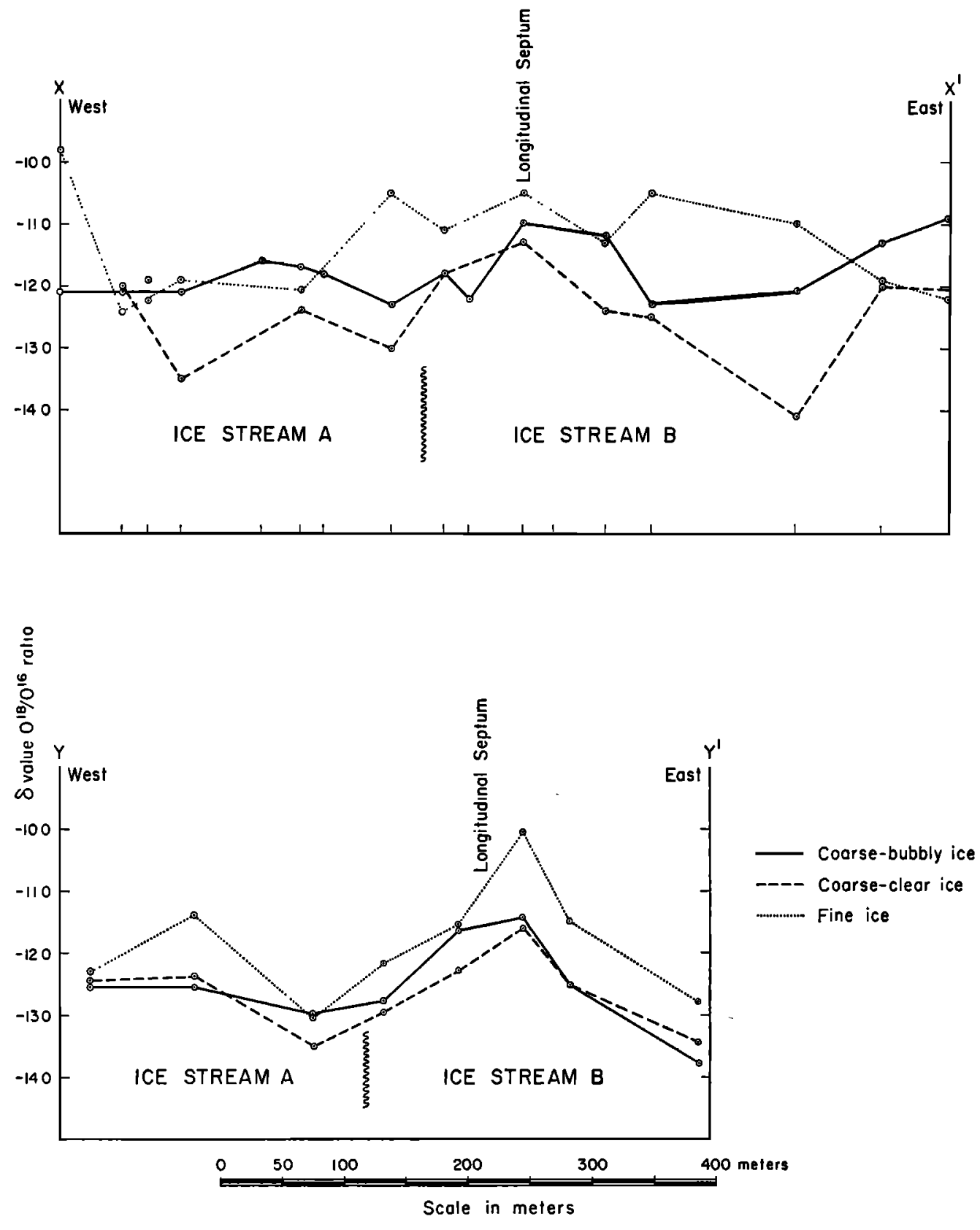

Fig. 6. Plots of oxygen-isotope variation in samples of coarse-bubbly, coarse-clear, and fine ice along transverse profiles across lower Blue Glacier; Fig. 5 for location. 
TABLE 6. The $\delta$ Values for Coarse-Bubbly, Coarse-Clear, and Fine Ice

\begin{tabular}{|c|c|c|c|c|c|}
\hline \multirow[b]{2}{*}{ Location } & \multirow{2}{*}{$\begin{array}{l}\text { Coarse- } \\
\text { Clear } \\
\text { Ice }\end{array}$} & \multirow{2}{*}{$\begin{array}{l}\text { Fine } \\
\text { Ice }\end{array}$} & \multirow{2}{*}{$\begin{array}{c}\text { Coarse- } \\
\text { Bubbly } \\
\text { Ice }\end{array}$} & \multicolumn{2}{|c|}{ Difference } \\
\hline & & & & $\mathrm{CCI}-\mathrm{CBI}$ & FI - CBI \\
\hline \multirow{12}{*}{$\begin{array}{l}\text { At base of western icefall } \\
6 \mathrm{~m} \text { downglacier from icefall } \\
225 \mathrm{~m} \text { downglacier from icefall } \\
\text { Dark ogive band opposite base camp } \\
\text { White ogive band opposite base camp } \\
\text { Dark ogive band opposite base camp } \\
\text { White ogive band opposite base camp } \\
\text { Dark ogive band opposite base camp } \\
\text { Longitudinal septum opposite base camp } \\
6 \mathrm{~m} \text { from west rock wall below TP-5 (Fig. 5) }\end{array}$} & 122 & -11.6 & -11.8 & 00 & +0.2 \\
\hline & $\begin{array}{l}-13.5 \\
-13.5\end{array}$ & -11.4 & -12.1 & $\begin{array}{l}-0.9 \\
-1.4\end{array}$ & +0.7 \\
\hline & -13.1 & -11.3 & -12.3 & -0.8 & +1.0 \\
\hline & -12.5 & -13.0 & -12.2 & -0.3 & -0.8 \\
\hline & -14.1 & -11.3 & -13.7 & -0.4 & +2.4 \\
\hline & -10.5 & -11.7 & -12.1 & +1.6 & +0.4 \\
\hline & -12.7 & $\begin{array}{l}-11.5 \\
-10.7\end{array}$ & $\begin{array}{l}-12.7 \\
-12.5\end{array}$ & 0 & $\begin{array}{r}+1.2 \\
+1.8\end{array}$ \\
\hline & & -9.8 & -12.1 & & +2.3 \\
\hline & {$[-12.0$} & -12.4 & -12.1 & +.1 & -0.3 \\
\hline & -13.5 & -11.9 & -12.0 & -1.5 & +0.1 \\
\hline & $\begin{array}{l}-12.4 \\
-13.0\end{array}$ & $\begin{array}{l}-12.0 \\
-10.5\end{array}$ & $\begin{array}{l}-11.7 \\
-12.3\end{array}$ & $\begin{array}{l}-0.7 \\
-0.7\end{array}$ & $\begin{array}{l}-0.3 \\
+1.8\end{array}$ \\
\hline & -11.8 & -11.1 & -11.8 & 0 & +0.7 \\
\hline \multirow[t]{5}{*}{ Upper transverse profile $X X^{\prime}$ (Fig. 5) } & -11.3 & -10.5 & -11.0 & -0.3 & +0.5 \\
\hline & $\begin{array}{l}-12.4 \\
-12.5\end{array}$ & $\begin{array}{l}-11.3 \\
-10.5\end{array}$ & $\begin{array}{l}-11.2 \\
-12.3\end{array}$ & -1.2 & $\begin{array}{l}-0.1 \\
+18\end{array}$ \\
\hline & -14.1 & -11.0 & -12.1 & -2.0 & +1.1 \\
\hline & -12.0 & -11.9 & -11.3 & -0.7 & -0.6 \\
\hline & & -12.2 & -10.9 & & -1.3 \\
\hline Center of ice stream A opposite TP-5 (Fig. 5) & -13.0 & -12.4 & -12.1 & -0.9 & -0.3 \\
\hline East edge of stream B opposite TP-5 & -13.4 & -11.0 & -14.0 & +0.6 & +3.0 \\
\hline Center of stream A opposite TP-4 (Fig. 5) & -12.6 & -12.0 & -12.4 & -0.2 & +0.4 \\
\hline West part of stream B opposite TP-4 & -12.3 & -11.1 & -11.4 & -0.9 & +0.3 \\
\hline East part of stream B opposite TP-4 & -13.0 & -11.1 & -12.8 & -0.2 & +1.7 \\
\hline & -12.4 & -12.3 & -12.5 & +0.1 & +0.2 \\
\hline & -12.4 & -11.4 & -12.5 & +0.1 & +1.1 \\
\hline & -13.5 & -13.0 & -13.0 & -0.5 & 0 \\
\hline Lower transverse profile $Y Y^{\prime}$ (Fig. 5) & -13.0 & -12.2 & -12.8 & -0.2 & +0.6 \\
\hline & -12.3 & -11.5 & -11.6 & -0.7 & +0.1 \\
\hline & -11.6 & -10.0 & -11.4 & -0.2 & +1.4 \\
\hline & -12.5 & -11.5 & -12.5 & 0 & +1.0 \\
\hline & & -12.8 & -13.8 & +0.4 & +1.0 \\
\hline \multirow{2}{*}{\multicolumn{2}{|c|}{$\begin{array}{l}\text { West medial moraine } 300 \mathrm{~m} \text { above terminus } \\
\text { East margin } 200 \mathrm{~m} \text { above terminus }\end{array}$}} & -11.7 & -12.6 & & \\
\hline & & -12.2 & -12.6 & & +0.4 \\
\hline
\end{tabular}

found in a pod of coarse-clear ice with a $\delta$ of -8.6 completely surrounded by fine ice with a ratio of -9.8 .

On the basis of $\delta$ values and field relations, it is suggested that the masses of coarse-clear ice may originate in at least two ways: (1) Coarseclear ice with a $\delta$ higher than that of the associated ice may represent local bodies of material that gradually recrystallized while soaked with water. Since most meltwater and rain water are richer in $\mathrm{O}^{20}$ than most of the underlying snow, firn, or ice, incorporation of such water by recrystallization would produce a higher $\delta$. Reference is not made here to refrozen pools of water filling moulins, crevasses, or other depressions. Bodies of ice formed in this manner, although relatively abundant, are so readily recognized by their distinctive form and crystal structure that there is little chance of confusing them with the masses of coarse-clear ice under consideration. (2) Bodies of coarse-clear ice with $\delta$ values lower than those of the associated coarse-bubbly ice may represent chunks of deeper and older ice which became mixed with surficial material in the icefall. Ice breccias containing fragments of coarse-grained bluish ice in a matrix of firn and fragmented ice have been observed near the base of the fall. If the bluish ice of the breccia represents deeper material, it should have a lower $\delta$ because it comes from higher in the accumulation basin.

The masses of coarse-clear ice in the ice tongue 
are much less bubbly than the breccia fragments. This could be due to an unusual degree of recrystallization experienced by these fragments because the orientation of their crystals was not well suited to the direction of stress at the base of the icefall. Recrystallization is the principal means by which ice grains in the breccia fragments could be reoriented and the clarity of the ice increased by reduction of air bubbles. This interpretation is supported by the fact that nearly all the ice near the glacier snout, which presumably has experienced much recrystallization, is much clearer than most ice farther upglacier. Ice along lateral margins of the glacier, where large crystals suggest considerable recrystallization, is also relatively clear.

Most fine ice has higher $\delta$ values than the associated coarse-bubbly ice, but in a few instances the values are the same or even lower (Table 6). The mean difference in 35 coarsebubbly and fine ice pairs is +0.7 , and the maximum is +3.0. Statistical analysis shows that this difference is not due to chance. In 8 out of the 35 pairs, the $\delta$ of fine ice is lower.

At some locations it is clear from direct observation that the fine ice represents insets of snow or firn filling crevasses. However, it is not clear from the field relationships that all fine ice in lower Blue Glacier originated in this manner. Some of the fine-ice bodies are lenses or pods, others are highly irregular in shape, and many are thin folia intimately associated with the other types of ice. If all the fine ice represents inset bodies of firn, the geometrical relations have been so greatly modified and the fine ice so closely incorporated into the prevailing foliation structure of the glacier that the inset mode of origin is no longer obvious. We have entertained the thought that some of the fine ice may be ground-up or recrystallized [Kamb, 1959, pp. 1896-1900] coarse-bubbly ice, but the $\delta$ values do not generally support these ideas. The $\delta$ values of fine ice in thin folia are roughly the same as the values for firn fillings in crevasses.

In general, snow filling a crevasse would be expected to have a higher $\delta$ than the ice of the crevasse walls, which represents material that accumulated at higher elevations. However, variations in the $0^{10} / 0^{10}$ ratio among individual snow storms are considerable (Table 3), and it is possible that snow accumulating in a crevasse may occasionally have about the same or even a lower $\delta$ than the adjacent ice. Thus, even fine ice with $\delta$ values lower than those in the associated coarse-bubbly ice may originate as insets of snow. The same explanation might also hold for the one example of fine ice with a $\delta$ lower than the coarse-clear ice mass it enclosed.

Transverse profiles. Variations in oxygenisotope ratios along profiles extending transversely across a glacier should reveal differences in the site of accumulation of the material composing individual ice streams. Samples were taken along two principal transverse profiles and along several shorter traverses across parts of the ice tongue of lower Blue Glacier. The uppermost profile ( $X X^{\prime}$, Fig. 5 ) is 150 to 250 meters below the firn edge. It starts at the west wall and crosses ice streams A, B, and C (Fig. 1). An apron of firn covers most of ice streams $D$ and E, so they were not sampled. The lower profile ( $Y Y^{\prime}$, Fig. 5) is $450 \mathrm{~m}$ above the snout and extends completely across the glacier from wall to wall. It involves only ice streams $A$ and $B$, the other streams having terminated farther upglacier. Data from the miscellaneous shorter traverses are not discussed, but they are consistent with results from the longer profiles.

Separate samples of coarse-bubbly, coarseclear, and fine ice were taken at each collection site along the principal transverse profiles. The $\delta$ values of these samples are plotted in Figure 6. One relationship immediately apparent is the difference in $\delta$ values of the three types of ice already discussed. If fine ice actually represents insets of firn, the difference in $\delta$ values between it and the accompanying coarse-bubbly ice should be greater along the lower profile because the coarse ice of the lower profile comes from higher in the accumulation basin. This proves to be the case.

The difference in the average 8 of coarsebubbly and coarse-clear ice is less on the lower profile than on the upper profile, -0.2 compared with -0.7 . This is consistent with the greater similarity in appearance of these two types of ice in the lower reach of the glacier and with the general evidence of homogenization, but the reasons for the relative changes in $\delta$ values are not known.

Useful comparisons of the different ice streams can be made on the basis of $\delta$ values in coarsebubbly ice alone. Along profile $X X^{\prime}$ these values have only a small range within ice stream $A$ and 
are about the same in both ice streams A and B. This is to be expected, as both streams originate in accumulation basins having a similar morphology and essentially the same elevation. The only marked departure is within ice stream B at the crossing of the longitudinal septum where the $\delta$ values are distinctly higher than average (Fig. 6). This is consistent with the preferred hypothesis of origin for this feature involving the incorporation of a large amount of snow and firn in and at the base of the icefall [Allen, Kamb, Meier, and Sharp, 1960].

Samples from the lower profile show essentially the same features as the upper profile, including higher $\delta$ values in the longitudinal septum. The low $\delta$ at the east end of the lower profile ( $Y Y^{\prime}$, Fig. 6) may be due to excessive marginal ablation, which exposes relatively deeper ice. Lack of a correspondingly low value at the west end of the profile could be due to a much lower ablation related to shaded exposure and to protection afforded by residual snow banks. In general, ice along the margins would be expected to have somewhat lower $\delta$ values because of the slower velocity, which gives opportunity for exposure of deeper ice by greater melting.

Longitudinal profiles. Deductions concerning longitudinal lines of flow in a valley glacier suggest that ice appearing on the surface at positions progressively farther below the firn edge came from successively higher parts of the accumulation area. If this is correct, the $\delta$ values should become progressively lower from firn edge to glacier terminus.

To explore this relation, a series of composite samples ${ }^{3}$ was collected in 1958 along the center flow lines of ice streams A and B. In 1959, samples of coarse-bubbly ice alone were taken along the center flow line of ice stream $B$. The $\delta$ values of these samples are shown on the map (Fig. 5), and the values for the coarsebubbly ice alone are plotted in Figure 7.

The composite samples collected along the longitudinal profiles show no consistent trend in $\delta$ values (Fig. 5). Considering the possible ori-

A composite sample consists of emall chips of ice taken at ten separate spots distributed over an area not exceeding 10 to $12 \mathrm{~m}$ in radius. The three common types of ice are included in roughly the estimated proportions exposed on the surface at the sampling site. gins of fine and coarse-clear ice, this is perhaps not surprising. However, the samples of coarsebubbly ice do show a somewhat irregular but unmistakable decrease in $\delta$ downglacier (Fig. 7). Irregularities in these curves probably reflect local inhomogeneities within the ice left over from the firn. Although physical aspects of individual firn layers may be obscured within the glacier tongue, it is hardly likely that the considerable differences in $\delta$ values for individual firn layers (Fig. 4) are completely eliminated. Furthermore, variations related to secular climatic changes may exist and must involve large masses of ice. If allowances are made for such inhomogeneities, the case for a modest decrease in $\delta$ is acceptable.

A more reliable evaluation is perhaps afforded by comparison of the mean $\delta$ for all samples of coarse-bubbly ice taken along the two transverse profiles, $X X^{\prime}$ and $Y Y^{\prime}$ (Fig. 6). The mean value along the lower profile $(-12.5)$ is lower than the mean value along the higher profile $(-11.9)$. Other $\delta$ values for coarse-bubbly ice on the surface of the glacier, but not located on the longitudinal profiles (Fig. 5), confirm in general the trend toward lower values downglacier. Thus, data from Blue Glacier offer modest support to the deductions of Reid [1896, p. 919] concerning flow lines in a valley glacier.

Oxygen-isotope ratios in ogives. The ogives of lower Blue Glacier appear as lunate, alternate white and darker bands on the surface of ice stream A below the firn edge. The white bands average roughly $25 \mathrm{~m}$ in width, the darker bands $5 \mathrm{~m}$. These bands represent the outcrop traces of layers of material within the glacier. The white bands are 90 to 95 per cent coarsebubbly ice, and the darker bands are a more heterogeneous mixture of coarse-bubbly, fine (up to 35 per cent), and coarse-clear ice (up to 10 per cent). The origin of these ogives is a matter of speculation, but one hypothesis [Allen, Kamb, Meier, and Sharp, 1960] is that the darker bands represent insets of ice breccia that accumulated in icefall crevasses. It is interesting to see what light the $0^{10} / 0^{18}$ ratios can throw on the origin of these structures.

The samples analysed came from two different but closely associated sets of ogives, representing two white and three darker bands. The $\delta$ values for fine and coarse-clear ice display wide variations (Table 7), presumably for reasons 
TABLE 7. Oxygen-Isotope Ratios of Materials Composing Ogive Bands of Blue Glacier

\begin{tabular}{|c|c|c|c|}
\hline & $\begin{array}{c}\text { Type of } \\
\text { Band }\end{array}$ & $\begin{array}{l}\text { Nature of } \\
\text { Material }\end{array}$ & $\begin{array}{l}\delta \mathrm{Valu}^{\theta} \\
\mathrm{O}^{18} / \mathrm{O}^{10}\end{array}$ \\
\hline \multirow[t]{2}{*}{ Ogive set 1} & White (1w) & $\begin{array}{l}\text { Composite* } \\
\text { Coarse-bubbly ice } \\
\text { Fine ice } \\
\text { Coarse-clear ice }\end{array}$ & $\begin{array}{l}-12.2 \\
-12.1 \\
-11.7 \\
-10.5\end{array}$ \\
\hline & Dark $(1 d)$ & $\begin{array}{l}\text { Composite* } \\
\text { Coarse-bubbly ice } \\
\text { Fine ice } \\
\text { Coarse-clear ice }\end{array}$ & $\begin{array}{l}-12.4 \\
-12.7 \\
-11.5 \\
-12.7\end{array}$ \\
\hline \multirow[t]{3}{*}{ Ogive set 2} & Dark $(2 d)$ & $\begin{array}{l}\text { Coarse-bubbly ice } \\
\text { Fine ice } \\
\text { Coarse-clear ice }\end{array}$ & $\begin{array}{l}-12.3 \\
-11.3 \\
-13.1\end{array}$ \\
\hline & White $(2 w)$ & $\begin{array}{l}\text { Coarse-bubbly ice } \\
\text { Fine ice } \\
\text { Coarse-clear ice }\end{array}$ & $\begin{array}{l}-12.2 \\
-13.0 \\
-12.5\end{array}$ \\
\hline & Dark (2d) & $\begin{array}{l}\text { Coarse-bubbly ice } \\
\text { Fine ice } \\
\text { Coarse-clear ice }\end{array}$ & $\begin{array}{l}-13.7 \\
-11.3 \\
-14.1\end{array}$ \\
\hline
\end{tabular}

* A composite sample consists of small chips of ice taken at ten separate locations within a radius of 10 to 12 meters, representing the three types of ice in approximately their estimated abundance.

already discussed. The $\delta$ of coarse-clear ice in white band $1 w$ is higher and the $\delta$ of fine ice in white band $2 w$ is lower than would normally be expected. The significance of this is not readily apparent. The $\delta$ of coarse-bubbly ice is lower in the darker bands than in the white bands, the averaged difference being 0.7 . A possible explanation of this is that the insets of ice breccia contain considerable deep ice which has lower $\delta$ values. Possibly, this could come about by avalanching and crevasse-wall calving in the icefall.

Summary and conclusions. The oxygen-isotope data from Blue Glacier lead to some relatively straightforward, definite conclusions and lend support to certain interpretations and speculations, but they also raise many questions to which there are as yet no clear answers. This is not unexpected in view of the complexities of the Blue Glacier environment and the formative stage of oxygen-isotope studies of glacier materials.

The Blue Glacier analyses show the usual decrease in $\delta$ with increasing altitude, the rate being $0.5 / 100 \mathrm{~m}$. This behavior is not unique to snow, as it characterizes many types of precipitation [Epstein, 1956]. The Blue Glacier data also show that homogenization of oxygen isotopes begins shortly after snow accumulates, and significant effects are evident within a few months. It appears that much homogenization is effected in the accumulation area through refreezing of downward percolating water derived from melting of surface snow and from rain. The effects of vapor transfer and diffusion of oxygen are matters of speculation. Further homogenization occurs within the ice tongue during flow, but the processes causing it are not known. They may involve recrystallization, changes of state, and diffusion. The homogenization is of local extent and does not destroy largescale heterogeneities in $\delta$ values which can be used to study and interpret glacier structure and behavior.

Differences in $0^{19} / 0^{16}$ ratios proved to be a useful aid in understanding some of the structures within the ice tongue of the Blue Glacier. They indicate that thin layers of fine ice in the foliation pattern represent greatly drawn out masses of firn incorporated into the glacier by infolding or insetting, largely within and at the base of the icefall. The $0^{18} / 0^{10}$ ratios support the interpretation that creation of the longitudinal septum, a major structural feature, occurs near the base of the icefall and involves the incorporation of large amounts of snow and firn. The hypothesis that ogive dark bands represent greatly modified insets of firn-ice breccia filling icefall crevasses is supported by the oxygenisotope data. Variations in $\delta$ values also attest to the probable validity of deductions concerning longitudinal flow lines within a valley glacier by showing that ice near the terminus probably comes from the higher parts of the accumulation area.

On the other hand, the present studies do not contribute significantly to an understanding of the fundamental control of $0^{18} / \mathrm{O}^{10}$ ratios exercised by various aspects of the meteorological environment. Processes of homogenization, particularly within the ice tongue, remain largely unknown. Study of other glaciers in different climatological environments is in order. They should be of simple geometry with the least number of complicating influences. Sampling constitutes a major problem which cannot be 


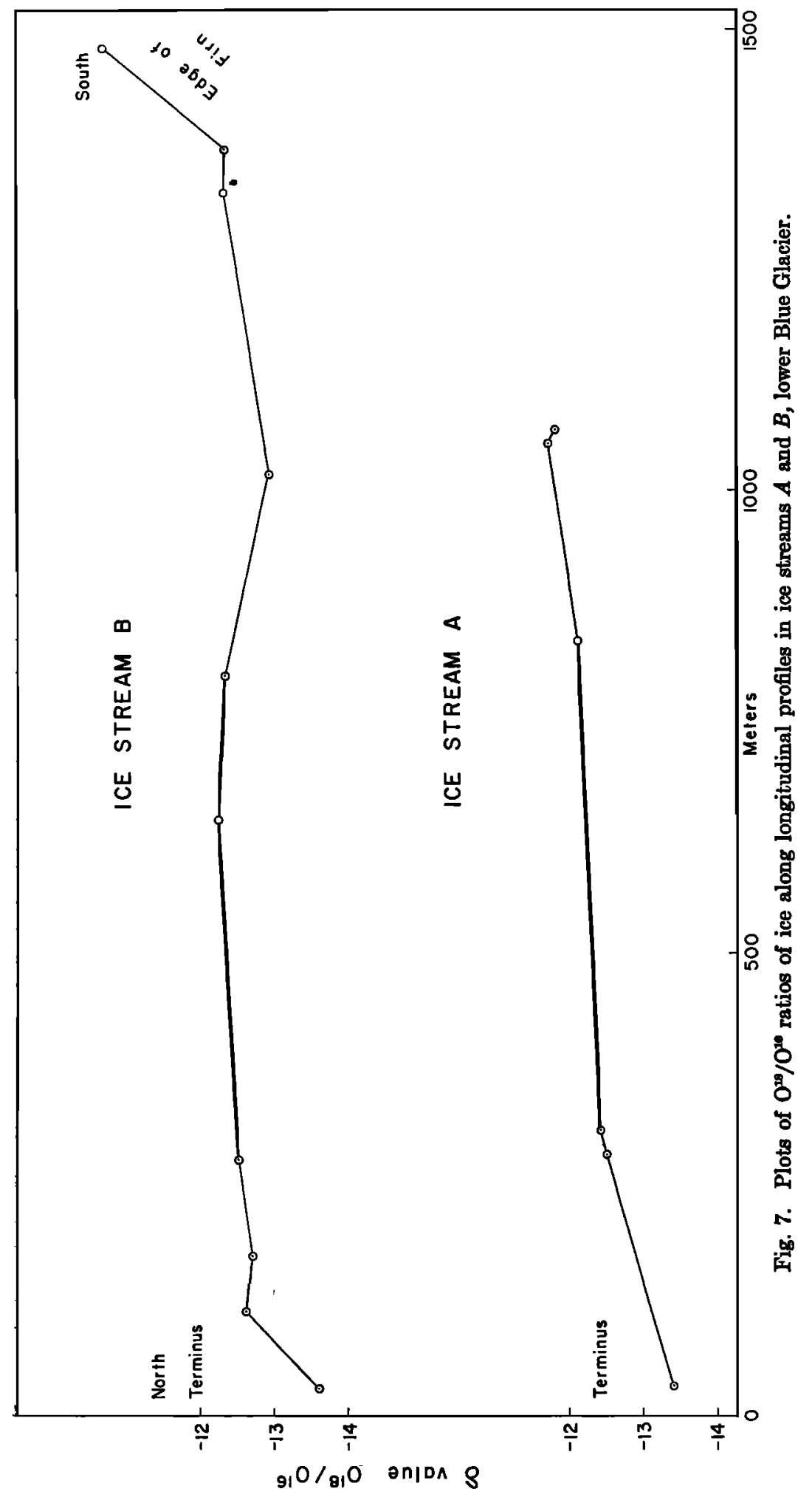


intelligently handled without a thorough understanding of the structure and constitution of the glacier. Analyses of samples from properly situated deep core holes in valley glaciers could be significant. Ultimately, a classification of glaciers in terms of the value and range of $0^{18} /$ $\mathrm{O}^{11}$ ratios should be possible. This is something for the future, and a number of glaciers in different environments must be studied first.

Acknowledgments. The work of 1957 and 1958 on Blue Glacier was an International Geophysical Year activity under the auspices of the U. S. National Committee. The investigation was continued in 1959 with support from the National Science Foundation. The mass spectrometer used for oxygen-isotope analyses is the property of the Atomic Energy Commission. The National Park Service graciously granted permission to make the study and aided in many ways. Supplies and equipment were carried to the glacier by the U. S. Air Force and the U. S. Coast Guard. Equipment was loaned by the Snow, Ice and Permafrost Research Establishment of the U. S. Army Engineers and by the Office of Naval Research (contract N-1896-00). Personnel of the Snowdome project on upper Blue Glacier collected samples of snow during the winter of 1957-1958. Field colleagues C. $R$. Allen and J. C. Savage aided in the collection of other samples. William R. Fairchild of the Angeles Flying Service provided superb logistical support. John Nye, Henri Bader, and Edward Anders have kindly offered critical and much appreciated comments on the manuscript, but they do not necessarily endorse any statements made in this paper.

\section{REFERENCES}

Allen, C. R., W. B. Kamb, M. F. Meier, and R. P. Sharp, Structure of the lower Blue Glacier, Washington, in press, 1960.

Benson, C. S., Stratigraphy in snow and firn of the Greenland ice sheet, Ph.D. thesis, Calif. Inst. of Technology, 213 pp., 1960.

Epstein, Samuel, Variation of the $0^{19} / 0^{18}$ ratio of fresh water and ice, Publ. 400, U. S. Natl. Acad. Sci., 20-28, 1956.

Epstein, Samuel, The variation of the $0^{18} / O^{16}$ ratio in nature and some geologic implications, $R e$ searches in Geochemistry, John Wiley \& Sons, New York, 217-240, 1959.

Epstein, Samuel, and T. Mayeda, Variation of $\mathrm{O}^{13}$ content of waters from natural sources, Geochim. et Cosmochim. Acta, 4, 213-224, 1953.

Epstein, Samuel, and R. P. Sharp, Oxygen-isotope variations in the Malaspina and Saskatchewan glaciers, J. Geol., 67, 88-102, 1959.

Hubley, R. C., Glaciers of the Washington Cascades and Olympic Mountains; their present activity and its relation to local climatic trends, J. Glaciol., \&, 669-673, 1956.

Hubley, R. C., Glacier research on Mt. Olympus, Olympic National Park, Washington, Arctic Institute of North America, mimeographed, $12 \mathrm{pp}$., 1957.

IGY Bulletin, Oxygen isotope studies, Trans. Am. Geophys. Union, 40, 81-84, 1959.

Kamb, W. B., Ice petrofabric observations from Blue Glacier, Washington, in relation to theory and experiment, J. Geophys. Research, 64, 1891$1909,1959$.

Klebelsberg, R. v., Handbuch der Gletscherkunde und Glacialgeologie, 1, Springer, Vienna, 403 pp., 1948.

LaChapelle, E. R., Blue Glacier, preliminary report on the scientific investigations, USNC-IGY Project 4.3, Dept. Meteorol. Climatol., Univ. Washington, mimeographed, 28 pp., 1958.

LaChapelle, E. R., Annual mass and energy exchange on the Blue Glacier, J. Geophys. Research, 64, 443-449, 1959.

Landsberg, H. E., Note on the recent climatic fluctuation in the United States, J. Geophys. Research, 65, 1519-1525, 1960.

Reid, H. F., The mechanics of glaciers, J. Geol., 4, 912-928, 1896.

Sharp, R. P., Features of the firn on upper Seward Glacier, St. Elias Mountains, Canada, J. Geol., 59, 599-621, 1951.

(Manuscript received July 9, 1960.) 